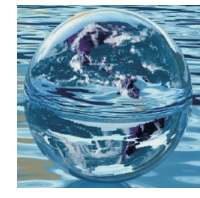

Journal homepage: www. fia.usv.ro/fiajournal Journal of Faculty of Food Engineering,

Ştefan cel Mare University of Suceava, Romania

Volume XX, Issue 2-2021, pag. 165 - 171

\title{
EFFECT OF ESSENTIAL OIL OF PIMENTA RACEMOSA ON MICROFLORA AFFECTING QUALITY OF AFRICAN MUSTARD OBTAINED FROM FERMENTED SEEDS OF PARKIA BIGLOBOSA JACK. P. BR
}

\author{
*Euloge S. ADJOU ${ }^{1}$, T. U. Makosso Antoine ALLAVO ${ }^{1}$, Oscar AKOTOWANOU ${ }^{1}$, \\ Jasmine A. KOGBETO ${ }^{1}$, Audray VODOUNOU ${ }^{1}$, Dominique C.K. SOHOUNHLOUE ${ }^{1}$ \\ ${ }^{1}$ Laboratory of Study and Research in Applied Chemistry, University of Abomey-Calavi, Polytechnic School of \\ Abomey-Calavi, 01, P. O. Box 2009, Cotonou. \\ eulogesenan@yahoo.fr. \\ * Corresponding author \\ Received $23^{\text {th }}$ May 2021, accepted $29^{\text {th }}$ June 2021
}

\begin{abstract}
The present study aims to investigate the effect of essential oil of Pimenta racemosa on the microflora affecting the marketable quality of African mustard obtained from fermented seeds of Parkia biglobosa. Essential oil of Pimenta racemosa was extracted by hydrodistillation. Different types of African mustard were produced by the modification of the traditional processing technology and the introduction of a step of essential oil adjunction during the process. Three different essential oil concentrations (1.0, 2.0 and $3.0 \mu \mathrm{Lg}$-1) were investigated. Microbiological analyzes were performed in order to evaluate the quality of the African mustard produced. Results obtained revealed that the essential oil has inhibition property against the growth of total flora and fungi affecting marketable quality of African mustard during eight (08) days of storage, at the concentrations tested. However, bacterial growth was continuous and exponential in control samples. This supports the antimicrobial properties of the leaves of Pimenta racemosa and its traditional use as food ingredient. It is therefore suggested that further studies be carried out to isolate, purify and identify all active compounds present in all part of this plant.
\end{abstract}

Key words: Pimenta racemosa, Parkia biglobosa, African mustard, essential oil, biological activities

\section{Introduction}

The availability of good urban food is a major challenge facing African cities nowadays. The problem of urban food supply will intensify in the next future, given the "explosive" growth of urban poles, the rural exodus and the evolution of food behaviors associated with urbanization and the rapid adoption of imported food products [1]. However, the food supply of cities does not depend solely on the good articulation of agricultural production with the areas of consumption. It also depends on the urban food organization, which is complex due to the multiplicity of relationships and interactions between socio-economic actors, institutions and market conditions [1]. In this case food industry also plays a preponderant role through agro-food processing. This sector involves a majority of women who know certain traditional skills that they value.

Traditionally fermented condiments come from a very old empirical knowledge [2]. It is a process of natural fermentation of protein and oil seeds including those of Parkia biglobosa, Adansonia digitata, Arachis hypogeae, Hibiscus sabdariffa and Glycine max [2]. These fermentations lead to the involvement of lactic acid bacteria, yeasts and molds, which, through their numerous lytic activities, modify the 
biochemical, nutritional and sensory characteristics of transformed seeds [3]. These sensory modifications participate in the typicality of these African mustards.

In Benin, African mustard commonly called " Afitin" is a traditional condiment produced from fermented seeds of Néré (Parkia biglobosa) by different sociocultural and sociolinguistic groups [4]. In addition, according to Gutierrez et $a l$. [1], it is accepted in public opinion that this traditional condiment would have medicinal properties, which also explains the high consumption rate observed. But, because of their high water content and the presence of nutrients, traditional condiments provide a favorable environment for the development of microorganisms. However, during fermentation, lactic acid bacteria produce many natural antimicrobial compounds, such as lactic acid, acetic acid, formic acid, and caproic acid, carbon dioxide, hydrogen peroxide, diacetyl, ethanol and bacteriocins [5]. Indeed, the production of organic acids and antimicrobial compounds during fermentation leads to a decrease in $\mathrm{pH}$ that makes difficult the development of pathogenic bacteria [5]. In opposition, the development of fungi affecting marketable quality has been reported in fermented food products by Degnon et al. [4]. Moreover, there is nowadays more restrictions imposed by international food organism on the use of chemical synthesis food preservatives, which increasingly encourage the use of essential oils in food preservation [6]. Their applications as preservatives in food or antiseptics and disinfectants have been widely investigated [7]. Some components present in essential oils are classified as generally recognized as safe substances and therefore can be used to prevent postharvest growth of native and contaminant bacteria. Then many areas of food science are concerned about the use of essential oils. In food products, essential oils have been used in bakery [8], cheese [9], meat [10], and fruit [11], among others. The advantage of essential oils is their bioactivity in the vapor phase, a characteristic that makes them useful as possible fumigants for stored commodity protection. Then, plants belonging to Myrtaceae family like Pimenta racemosa have retained the attention of researchers, not only because of their high diversity and their distribution around the world, but also for their variable use in popular medicines to treat diseases [12]. In Benin, the leaves of this plant are used in culinary preparations where the species is known as "laurel leaf'. Thus the present study aims to investigate the effect of essential oil of Pimenta racemosa on the microflora affecting the marketable quality of African mustard obtained from fermented seeds of Parkia biglobosa.

\section{Materials and methods}

\section{2-1-Collection of plant leaves}

Plant materials used for essential oil (EO) extraction were fresh leaves from Pimenta racemosa. Plants were collected at Abomey-calavi (southern Benin) and identified at the Benin national herbarium, where voucher specimens are deposited.

\section{2-2-Essential oil extraction}

The EO tested was extracted by the hydrodistillation method using Clevenger-type apparatus. The oil recovered was dried over anhydrous sodium sulfate and stored at $4{ }^{\circ} \mathrm{C}$ until it was used [13].

\section{2-3-Local mustard production and experimental process}

The choice of production technology as well as the selection of women who participated in the present study were made thanks to a prospecting mission carried out in partnership with 'Solidarités Entreprises Nord-Sud" (SENS-Benin). The technology of local mustard

Euloge S. ADJOU, T. U. Makosso Antoine ALlAVo, Oscar AKOTOWANOU, Jasmine A. KOGBETO, Audray VODOUNOU, Dominique C.K. SOHOUNHLOUE, Effect of essential oil of Pimenta racemosa on microflora affecting quality of african mustard obtained from fermented seeds of Parkia Biglobosa Jack. P. Br, Food and Environment Safety, Volume XX, Issue 2-2021, pag. $165-171$ 
production used in this experimentation can be described as follows: P. biglobosa seeds are collected and cleaned. Then they were cooked. The cooked seeds are then shelled to separate the seed coat from the cotyledons. Then comes the step of rinsing with water to rid the cotyledons of their already softened shell. After selective sorting, the cotyledons are rinsed again and soaked for hours. They then undergo a second cooking. After cooling, they are fermented for 12 hours at room temperature. The cotyledons thus fermented are then salted and ground to obtain a paste which is packaged in the form of balls (Figure 1). The local mustards thus produced are divided into four batches called A, B, C and D. The first three batches received the respective doses of 1.0, 2.0 and $3.0 \mu 1 . \mathrm{g}^{-1}$ of essential oil. The last batch (D) did not receive any essential oil and is considered as a control. The batches of local mustards thus treated are stored at $25{ }^{\circ} \mathrm{C}$. Periodic sampling followed by inspections and analyzes made it possible to follow the evolution of the microbial flora during storage.

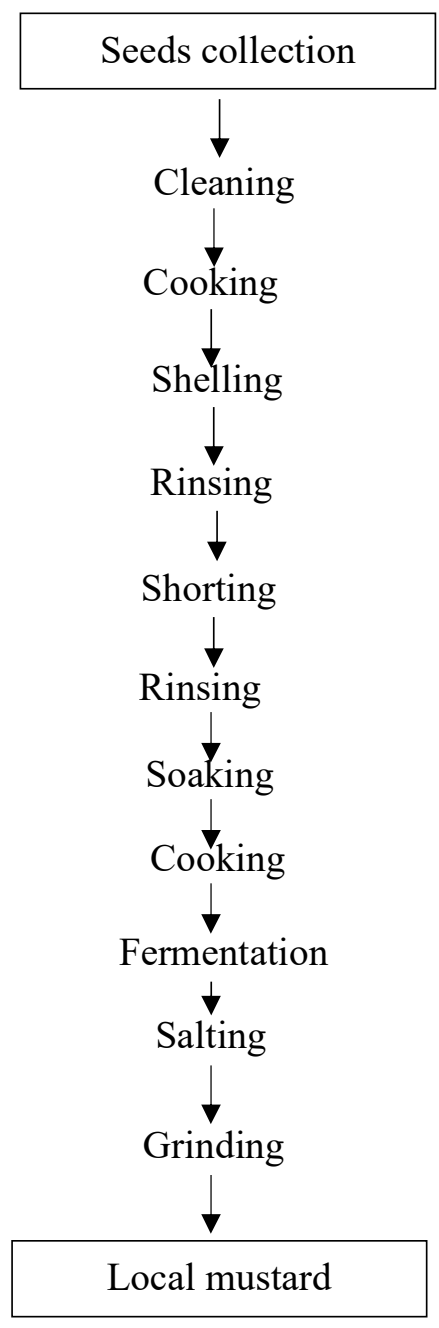

Fig. 1. Process diagram of local mustard production

Euloge S. ADJOU, T. U. Makosso Antoine Allavo, Oscar AKOTOWANOU, Jasmine A. KOGBETO, Audray VODOUNOU, Dominique C.K. SOHOUNHLOUE, Effect of essential oil of Pimenta racemosa on microflora affecting quality of african mustard obtained from fermented seeds of Parkia Biglobosa Jack. P. Br, Food and Environment Safety, Volume XX, Issue 2-2021, pag. $165-171$ 


\section{2-4-Microbiological Analysis}

To $25 \mathrm{~g}$ of each sample, $225 \mathrm{ml}$ of peptone water was added and homogenized. From the initial concentration, appropriate decimal dilutions were prepared and aliquots were plated in duplicates on various media. Plate count agar was used for the total bacterial count. Plates were incubated at $30^{\circ} \mathrm{C}$ for $72 \mathrm{~h}$. After incubation, the number of colonies was tracked using a colony counter. The number of bacteria expressed as Colony Forming Units per gram $(\mathrm{CFU} / \mathrm{g})$ was then determined by calculation, considering the factors of dilution.

The method used for detection of fungi in samples was performed using dilution plating method. $10 \mathrm{~g}$ of each sample were separately added to $90 \mathrm{ml}$ of sterile water containing $0.1 \%$ peptone water. This was thoroughly mixed to obtain the $10^{-1}$ dilution. Further tenfold serial dilutions up to $10^{-4}$ were made. One milliliter of each dilution was separately placed in Petri dishes, over which $10-15 \mathrm{ml}$ of Potato Dextrose Agar with $60 \mu \mathrm{g} / \mathrm{ml}$ of chloramphenicol (PDAC) was poured. The plates were incubated at $28 \pm 2^{\circ} \mathrm{C}$ for 7 days [14]. All media used for microbiological analysis were prepared as indicated by the manufacturer.

\section{2-5-Statistical Analyses}

The data generated from these studies were analyzed using Statistical Analysis Software (SAS) and SYSTAT 5.05. [15].

\section{Results and discussion}

Figures 2 and 3 present the results obtained during the evaluation of the effect of the essential oil of Pimenta racemosa in the preservation of African mustard obtained from the fermented seeds of Parkia biblobosa. These results indicate that the bacteria constituting the total flora of African mustard are sensitive to the essential oil of Pimenta racemosa (Figure 2 ). Indeed, the results of monitoring the evolution of the total flora during storage, showed a significant decrease in the microbial quantum in the African mustard samples that received the different concentrations of the essential oil, during the first eight days of storage. This antimicrobial effect of the essential oil depends on the dose tested because, at a dose of $3 \mu \mathrm{L}^{-\mathrm{g}^{-1}}$, the evolution of the total flora in the product is greatly slowed down, compared to the control samples (without essential oil). On the other hand, after eight days of storage, there is a gradual resumption of the growth of the total flora. These results are also in agreement with those obtained during the monitoring of the evolution of the fungal flora in the samples of African mustard supplemented with essential oil of Pimenta racemosa at different concentrations (Figure 3). Indeed, during the first eight days of storage, a significant decrease of fungal growth is also observed in samples with different doses of the essential oil of Pimenta racemosa, when compared to the control samples (without essential oil). These results indicated that the essential oil of Pimenta racemosa has an inhibitory activity on the microflora of African mustard at the concentrations tested. However, the resumption of microbial growth after eight days of conservation, could be related to the volatile nature of the essential oil.

The obtained results confirm the antibacterial properties of the essential oil of Pimenta racemosa, as reported by several research works, such as Adjou et al. [12] and Ismail et al., [16]. Food processing makes use of various unit operations and technologies to convert relatively perishable and typically inedible raw materials into more useful shelf-stable and palatable foods or potable beverages [17]. Processing also contributes to food security by minimizing waste and losses in the food chain and by increasing food availability and marketability. The

Euloge S. ADJOU, T. U. Makosso Antoine ALlAVo, Oscar AKOTOWANOU, Jasmine A. KOGBETO, Audray VODOUNOU, Dominique C.K. SOHOUNHLOUE, Effect of essential oil of Pimenta racemosa on microflora affecting quality of african mustard obtained from fermented seeds of Parkia Biglobosa Jack. P. Br, Food and Environment Safety, Volume XX, Issue $2-2021$, pag. $165-171$ 
fermentation bioprocess is the major biotechnological application in food processing. It is often one step in a sequence of food processing operations which may include cleaning, size reduction, soaking and cooking (Figure1). Fermentation bioprocessing uses microbial inoculants to enhance properties such as the taste, aroma, shelf-life, safety, texture and nutritional value of foods. In the present study, microbes associated with the raw food material such as seeds of Parkia biglobosa and the processing environment, serve as inoculants in this spontaneous fermentations. Several studies have also reported the high antimicrobial potential of this essential oil. Indeed, the antimicrobial activity of Pimenta racemosa oil, could be due to the presence in the oil of the main component with high antimicrobial activity such as eugenol [12]. Indeed, eugenol is a remarkably versatile molecule incorporated as a functional ingredient in numerous products and has found application in the pharmaceutical, agricultural, fragrance, flavour, cosmetic and various other industries. In addition, it is widely used in agricultural applications to protect foods from microorganisms during storage.

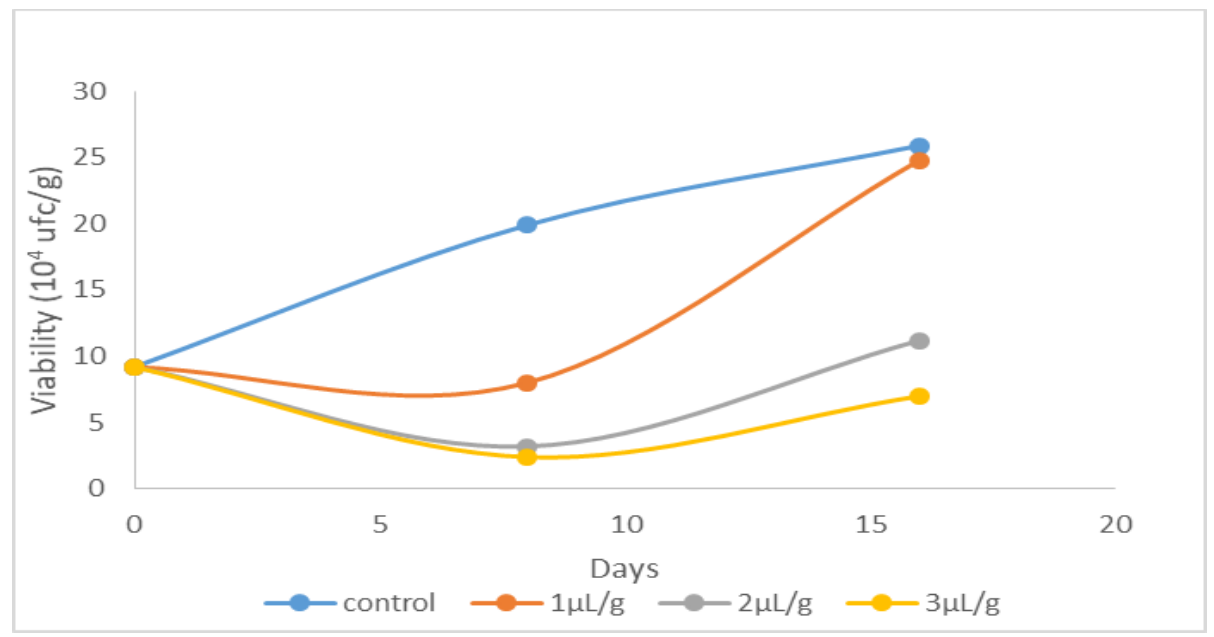

Fig. 2. Total bacterial count of African mustard samples during conservation

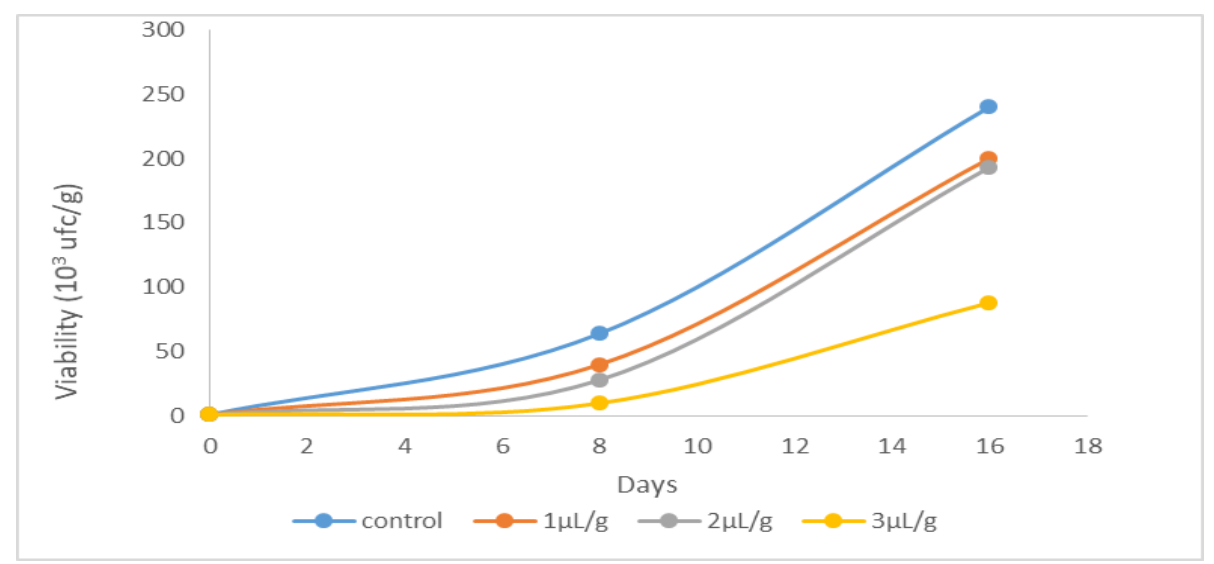

Fig. 3. Evolution of fungal flora count in African mustard samples during conservation

Euloge S. ADJOU, T. U. Makosso Antoine Allavo, Oscar AKotowanou, Jasmine A. KOGBeto, Audray VOdounOU, Dominique C.K. SOHOUNHLOUE, Effect of essential oil of Pimenta racemosa on microflora affecting quality of african mustard obtained from fermented seeds of Parkia Biglobosa Jack. P. Br, Food and Environment Safety, Volume XX, Issue 2-2021, pag. $165-171$ 


\section{Conclusion}

This research underlined the antimicrobial properties of essential oil of Pimenta racemosa against microflora affecting marketable quality of African mustard. Results indicate that the bacteria and fungi constituting the total flora of African mustard are very sensitive to the essential oil of Pimenta racemosa. Developing biocides from this essential oil would be also contributive for a lasting solution to the many problems posed by the use of synthetic antimicrobial products. However, in relation to the composition of foods, further investigations are also necessary to identify the conditions that maximize their antimicrobial activity without detrimental effects on the organoleptic properties of the African mustard.

\section{Acknowledgments}

The authors are grateful to 'Solidarités Entreprises Nord-Sud', (SENS-Benin) for their support.

\section{References}

[1]. GUTIERREZ M.L., MAIZI P., NAGO C.M., HOUNHOUIGAN D.J., Production et commercialisation de l'afitin dans la région d'Abomey-Bohicon au Bénin. Montpellier: CERNA, Cnearc, Cirad, (2000).

[2]. AZOKPOTA P., HOUNGBO H.Y., AKISSOE N.H., Aptitude stabilisatrice des conservateurs traditionnels de l'afitin, condiment africain à base de graines de néré (Parkia biglobosa Jack. P. Br). Cah Agric 20: 494-9, (2011).

[3]. IBEABUCHI J.C., OLAWUNI I.A., IHEAGWARA M.C., OJUKWU M., OFOEDU C.E., Microbiological Evaluation of 'Iru' and 'OgiriIsi' Used As Food Condiments. Journal of Environmental Science, Toxicology and Food Technology, 8: 45-50, (2014).

[4]. DEGNON R.G., KONFO C.T.R., ABOUDOU K., BAGBONON Y. M. G. G., Influence de la variété sur les caractéristiques microbiologiques, physico-chimiques et sensorielles du Afitin, un condiment produit à base de graines de soja au Bénin. International Journal of Innovation and Applied Studies 29(4): 11531160, (2020).

[5]. MOUROUFIE, A.K.J., EUDES S.K.P.A.N., KOUAKOU A.C., KOUAKOU E.K.V., KATI-COULIBALY, S., Review on the study of health effects of some fermented foods consumed on Côte d'Ivoire. Global Journal of Biology, Agriculture, Health Sciences 7 (3): 1-9, (2018).

[6]. ADJOU E.S., KOUTON S., DAHOUENON-AHOUSSI E., SOUMANOU M.M., SOHOUNHLOUE D.C.K., Effect of essential oil from fresh leaves of Ocimum gratissimum L. on mycoflora during storage of peanuts in Benin. Mycotoxin Res. 29: 29-38, (2013).

[7]. YEHOUENOU B., NOUDOGBESSI J.P., SESSOU P., WOTTO V., AVLESSI F., SOHOUNHLOUÉ C.K.D., Etude chimique et activités antimicrobiennes d'extraits volatils des feuilles et fruits de Xylopia aethiopica (Dunal) A. Rich. contre les pathogènes des denrées alimentaires. J Soc Ouest-Afr de Chim 29:19-27 (2010).

[8]. NIELSEN P.V., RIOS R., Inhibition of fungal growth on bread by volatile components from spices and herbs, and the possible application in active packaging with special emphasis on mustard essential oil. Int. J. Food Microbiol. 60, 219-229, (2000).

[9]. VAZQUEZ B.I., FENTE C., FRANCO C.M., VAZQUEZ M.J., CEPEDA A., Inhibitory effects of eugenol and thymol on Penicillium citrinum strains in culture media and cheese. Int. J. Food Microbiol. 67, 157-163, (2001).

[10]. QUINTAVALLA S., VICINI L., Antimicrobial food packaging in meat industry. Meat Sci. 62 : 373-380. (2002).

[11]. LANCIOTTI R., GIANOTTI A., PATRIGNANI F., BELLETI N., GUERZONI M.E., GARDINI F., Use of natural aroma compounds to improve shelf life and safety of minimally processed fruits. Trends Food Sci. Technol. 15: 201-208. (2004).

[12]. ADJOU, E.S., DEGNON, R.G., DAHOUENON-AHOUSSI E., SOHOUNHLOUE, D. C. K., Improvement of Fermented Fish Flour Quality Using Essential Oil Extracted from Fresh Leaves of Pimenta racemosa (Mill.) J. W. Moore. Natural Product and Bioprospecting 7(4): 299305, (2017)

[13]. DE BILLERBECK V.G., ROQUES C.G., BESSIERE J.M., FONVIEILLE J.L., DARGENT R., Effect of Cymbopogon nardus (L) W. Watson essential oil on the growth and morphogenesis of Aspergillus niger. Can J Microbiol 47:9-17, (2001).

Euloge S. ADJOU, T. U. Makosso Antoine ALlAVo, Oscar AKOTOWANOU, Jasmine A. KOGBETO, Audray VODOUNOU, Dominique C.K. SOHOUNHLOUE, Effect of essential oil of Pimenta racemosa on microflora affecting quality of african mustard obtained from fermented seeds of Parkia Biglobosa Jack. P. Br, Food and Environment Safety, Volume XX, Issue 2-2021, pag. $165-171$ 
[14]. RAMPERSAD F., LALOO S., LABORDE A., MAHARAJ K., SOOKHAI L., TEELUCKSINGH J., REID S., Bacteriological quality of raw oysters in Trinidad and the attitudes, knowledge and perceptions of the public about its consumption. In Epidemiological Infection 123, 241-250, (1999).

[15]. OGBEIBU A.E., Biostatistics, a Practical Approach to Research and Data Handling (Mindex Publishing Company Ltd., Benin City), p. 264, (2005).
[16]. ISMAIL M.M., SAMIR R., SABER F.R., AHMED S.R., FARAG M.A., Pimenta oil as a potential treatment for Acinetobacter baumannii wound infection: In Vitro and in vivo bioassays in relation to its chemical composition. Antibiotics 9: 679-695, (2020).

[17]. BARRETT T., FANG P., SWAMINATHAN B., Amplification methods for detection of food-borne pathogens. In H. Lee, S. Morse \& O. Slovak, eds. Nucleic acid amplification techniques: Application to disease diagnosis, Boston, USA, Eaton Publishing, 171-181, (1997).

Euloge S. ADJOU, T. U. Makosso Antoine ALlAVo, Oscar AKOTOWANOU, Jasmine A. KOGBETO, Audray VODOUNOU, Dominique C.K. SOHOUNHLOUE, Effect of essential oil of Pimenta racemosa on microflora affecting quality of african mustard obtained from fermented seeds of Parkia Biglobosa Jack. P. Br, Food and Environment Safety, Volume XX, Issue $2-2021$, pag. $165-171$ 